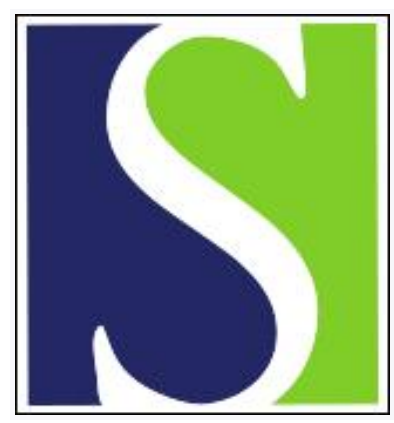

Scand J Work Environ Health 2008;34(6):438-443

https://doi.org/10.5271/sjweh.1288

Issue date: 00 Dec 2008

Sick leave among native and immigrant workers in Spain-a 6-month follow-up study

by Soler-González J, Serna M-C, Bosch A, Ruiz M-C, Huertas E, Rué M

Affiliation: CS Rambla de Ferran, Rambla de Ferran 44, 25007 Lleida, Spain. jorgesolergonzalez@gmail.com

Refers to the following texts of the Journal: $1997 ; 23$ suppl 1:12-19 2000;26(6):523-528 2007;33(2):96-104 2004;30(1):47-55

The following article refers to this text: $2010 ; 36(6): 515-516$

Key terms: absenteeism; follow-up study; immigrant worker; immigration; job satisfaction; migrant worker; native worker; occupational health; population dynamics; sick leave; sickness absence; socioeconomic inequality; Spain

This article in PubMed: www.ncbi.nlm.nih.gov/pubmed/19137205

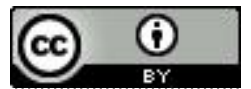




\title{
Sick leave among native and immigrant workers in Spain-a 6-month follow-up study
}

\author{
by Jorge Soler-González, MD, ${ }^{1}$ Maria-Catalina Serna, MD, ${ }^{2}$ Anna Bosch, MS-III, ${ }^{3}$ \\ Maria-Cristina Ruiz, MD, ${ }^{4}$ Elisard Huertas, BSc, ${ }^{5}$ Montserrat Rué, PhD ${ }^{6}$
}

\begin{abstract}
Soler-González J, Serna M-C, Bosch A, Ruiz M-C, Huertas E, Rué M. Sick leave among native and immigrant workers in Spain-a 6-month follow-up study. Scand J Work Environ Health 2008;34(6):438-443.

Objectives The incidence and duration of sick leave were studied among immigrants and the native-born population in Spain.

Methods This observational follow-up study included 1427 immigrants and 2793 Spanish natives treated at five primary care centers in Lleida in 2005 and followed for 6 months. The sick leave causes were coded according to the International Classification of Diseases (10th revision). Multivariate Poisson regressions estimated the rate ratio (RR) for sick leave adjusted for age, and linear regressions evaluated the effect of age, gender, and region of origin on the total number of sick-leave days.

Results Altogether $19.5 \%$ of the natives and $12.7 \%$ of the immigrants had at least one sick-leave episode. The incidence of new episodes per 100 person-years was lower for the immigrants than for the natives (32.5 versus 43.3 for the men and 18.6 versus 35.6 for the women, respectively). The mean duration of sick leave in the 6month period was 19.4 (SD 29.4) days for the immigrants and 33.5 (SD 39.2) days for the natives. For the men, the risk of sick leave was greater for the natives than for the immigrants (adjusted RR 1.70, 95\% confidence interval 1.43-2.02). After adjustment for age, the duration of sick leave for the native workers was 1.5 times greater than for the immigrants.

Conclusions Even though sick leave was less frequent among the immigrants than among the natives and the immigrant sick-leave periods were of shorter duration, the two study populations did not show differences in the causes of disability.
\end{abstract}

Key terms absenteeism; immigration; job satisfaction; migrant worker; occupational health; population dynamics; sickness absence; socioeconomic inequality.

Sick leave is a medical situation in which a patient is unable to work due to a common, not work-related illness. In Spain, sick leave is evaluated by a certified physician on the basis of a medical examination. Workers with sick leave receive a sickness benefit from the State.

In recent years, the situation of the working population in Spain has changed dramatically, primarily due to the unexpected increase in the immigrant population (1). Apart from immigration, other changes in the labor market include the effects of globalization on the organization of work and employment patterns, the possible loss of job security, the introduction of new technologies, the increasing age of the workforce, and the incorporation of women into the workforce (2). Strategies to prevent injury, especially among newly employed workers, should be based on a thorough understanding of these changes $(3,4)$.

In December 2005, immigrants represented a large proportion of the working population (12\% in Catalonia and $17 \%$ in Lleida) (5). These workers are essential to the Spanish economy. Since the phenomenon of immigration is recent in our country, few studies to date have addressed the issue of sick leave among immigrants.

1 Rambla de Ferran Health Center, University of Lleida, Lleida, Spain.

2 Regional Primary Care Management Office, University of Lleida, Lleida, Spain.

3 University of Lleida, Lleida, Spain.

4 Example Primary Care Health Center, Lleida, Spain.

5 Information systems. Institut Català de la Salut, Lleida, Spain.

6 Biomedical Research Institut, University of Lleida, Lleida, Spain.

Correspondence to: Dr J Soler-González, CS Rambla de Ferran, Rambla de Ferran 44, 25007 Lleida, Spain. [E-mail: jorgesolergonzalez@gmail.com] 
However, their level of job security is likely to be low and their work conditions poor (6).

Studies in Spain have highlighted differences in the health care services provided to immigrants and to the native-born population with regard to pharmaceutical consumption and the use of emergency hospital services $(7,8)$. However, no studies to date have analyzed sick leave among immigrants living in Spain, and only a few have concerned sick leave among immigrants in Europe (9-12).

This study was designed to identify possible differences in the incidence and duration of sick leave in immigrant and native-born populations.

\section{Study population and methods}

The study was designed as an observational follow-up study using an immigrant population and a random sample of the native-born population of Spain. Participants were included in the study sample between 1 March and 31 August 2005. All of them were followed for a period of 6 months.

Patients treated by 15 primary care physicians at five primary care centers in the city of Lleida (Spain), part of the Catalan Health Institute (ICS), took part in the study. The centers were located in the districts with the largest immigrant population, according to the municipal census. All of the immigrant patients seen by the participating physicians during the study period were included (a total of 1630 persons). To obtain the sample of the native-born population for the study, we selected 300 patients randomly from each of the 15 participating primary care centers. A total of 4500 persons were thus recruited. Of these, 346 were excluded after an individual review by the participating physicians, or due to recording errors. The final native-born sample comprised 4154 patients. From the total sample of 5784 patients, a subsample was selected of patients of working age, between 16 and 64 years. This subsample was comprised of 4220 persons (1427 immigrants and 2793 natives).

The participants' countries of origin were grouped into the following regions: Spain (native-born), Maghreb, Eastern Europe, Latin America, sub-Saharan Africa, other low-income countries (including Asian countries) and other high-income countries (13, 14). High-income countries were excluded from the study because there were very few persons from these countries in the sample. In this study, the natives were all patients born in Spain, and the immigrants were those from low- and middle-income countries. The immigrant samples were grouped together so that the statistical power of the study would be increased and more stable estimations would be obtained in the regression models.

\section{Variables}

We studied age, gender, country of origin, presence or absence of a new episode of sick leave due to common illness, total duration of sick leave in the 6-month follow-up period, and cause of sick leave coded using the International Classification of Diseases, 10th revision. These variables were obtained from the computerized database E-Cap V.10 of the Catalan Health Institute.

\section{Statistical analysis}

The incidence of a new episode of sick leave per 100 person-years and the total days of sick leave during the study period were estimated according to age, gender, and region of origin. The health problems that caused the sick leave were analyzed according to the assumption that the episode was the unit of analysis. A multivariate Poisson regression was used to estimate the age-adjusted rate ratio (RR) and 95\% confidence interval $(95 \% \mathrm{CI})$ for requiring sick leave with respect to the Spanish-born population while taking into account the age and gender distribution of each region of origin. A linear regression was used to evaluate the effect of the variables age, gender, and region of origin on the total number of days of sick leave. Given the asymmetric distribution of the variable total number of days of sick leave, a logarithmic transformation was applied. In both the Poisson and linear regressions, age was included in the models grouped into 10-year categories. Age-adjusted models were also obtained for each gender.

\section{Results}

Table 1 presents the demographic characteristics of the study population. The percentage of women and the mean age were slightly higher for the native-born group. The immigrants in the study sample were mainly from Latin America, Maghreb, and sub-Saharan Africa.

The percentage of persons requiring at least one period of sick leave during the study was greater for the natives (19.5\%) than for the immigrants (12.7\%). Table 2 presents the number of persons at risk and the incidence of sick leave. The incidence of, at least, a new episode of sick leave per 100 person-years was lower for the immigrants than for the natives (32.5 versus 43.3 for the men and 18.6 versus 35.6 for the women, respectively). For the age groups, differences were also observed between the immigrants and natives. The immigrants had less sick leave than the natives, and, in addition, their periods off work were shorter.

Table 3 presents the descriptive measures of sick leave duration, the higher means and medians being found for the native population than for the immigrants. 
Table 1. Characteristics of the study population and the incidence of a new episode of sick leave per 100 person-years, by group of origin.

\begin{tabular}{|c|c|c|c|c|}
\hline \multirow[t]{2}{*}{ Characteristic } & \multicolumn{2}{|c|}{ Immigrants $(\mathrm{N}=1427)$} & \multicolumn{2}{|c|}{ Natives $(\mathrm{N}=2793$ ) } \\
\hline & $\mathrm{N}$ & $\%$ & $\mathrm{~N}$ & $\%$ \\
\hline \multicolumn{5}{|l|}{ Gender } \\
\hline Male & 694 & 48.6 & 1246 & 44.6 \\
\hline Female & 733 & 51.4 & 1547 & 55.4 \\
\hline \multicolumn{5}{|l|}{ Age } \\
\hline \multicolumn{5}{|l|}{ Men a } \\
\hline 16-24 years & 110 & 15.9 & 203 & 16.3 \\
\hline $25-34$ years & 279 & 40.2 & 300 & 24.1 \\
\hline $35-44$ years & 213 & 30.7 & 297 & 23.8 \\
\hline $45-54$ years & 73 & 10.5 & 226 & 18.1 \\
\hline 55-64 years & 19 & 2.7 & 220 & 17.7 \\
\hline \multicolumn{5}{|l|}{ Women ${ }^{\mathrm{b}}$} \\
\hline 16-24 years & 187 & 25.5 & 252 & 16.3 \\
\hline 25-34 years & 270 & 36.8 & 373 & 24.1 \\
\hline $35-44$ years & 175 & 23.9 & 336 & 21.7 \\
\hline $45-54$ years & 82 & 11.2 & 277 & 17.9 \\
\hline 55-64 years & 19 & 2.6 & 309 & 20.0 \\
\hline \multicolumn{5}{|l|}{ Region of origin } \\
\hline Latin America & 448 & 31.4 & . & . \\
\hline Eastern Europe & 263 & 18.4 & . & . \\
\hline Maghreb & 406 & 28.5 & . & . \\
\hline Sub-Saharan Africa & 283 & 19.8 & . & . \\
\hline Other & 27 & 1.9 & . & . \\
\hline
\end{tabular}

a Mean 33.92 (SD 9.6) for the immigrants and mean 39.41 (SD 13.3) for the natives.

${ }^{b}$ Mean 32.39 (SD 10.1) for the immigrants and mean 39.80 (SD 13.8) for the natives.

Table 2. Incidence of sick leave by gender and group of origin.

\begin{tabular}{lccccc}
\hline Age $^{\text {a }}$ & \multicolumn{2}{c}{ Immigrants (N=1427) } & & \multicolumn{2}{c}{ Natives (N=2793) } \\
\cline { 2 - 3 } \cline { 5 - 6 } & $\begin{array}{c}\text { Sick leaves } \\
(\mathrm{N})\end{array}$ & $\begin{array}{c}\text { New } \\
\text { sick leaves/ } \\
\text { 100 person- } \\
\text { years }\end{array}$ & & $\begin{array}{c}\text { Sick leaves } \\
(\mathrm{N})\end{array}$ & $\begin{array}{c}\text { New } \\
\text { sick leaves/ } \\
\text { 100 person- } \\
\text { years }\end{array}$ \\
\hline Men & & & & \\
16-24 years & 16 & 29.2 & & 44 & 43.4 \\
25-34 years & 39 & 28.0 & & 76 & 50.6 \\
35-44 years & 41 & 38.6 & & 70 & 47.2 \\
45-54 years & 16 & 43.8 & & 52 & 46.0 \\
55-64 years & 1 & 10.6 & & 28 & 25.4 \\
16-64 years & 113 & 32.5 & & 270 & 43.3 \\
Women & & & & & \\
16-24 years & 7 & 7.4 & & 37 & 29.4 \\
25-34 years & 28 & 20.8 & & 88 & 47.2 \\
35-44 years & 22 & 25.2 & & 74 & 44.0 \\
45-54 years & 11 & 26.8 & & 41 & 29.6 \\
55-64 years & - & 0.0 & & 35 & 22.6 \\
16-64 years & 68 & 18.6 & & 275 & 35.6 \\
\hline
\end{tabular}

Among the men, the mean duration of sick leave was greater for the natives, with the exception of the 25- to $34-$ year age group. Among the women, work-related disabilities were always greater, on the average, for the
Table 3. Duration of sick leave by gender and group of origin.

\begin{tabular}{|c|c|c|c|c|c|c|c|c|}
\hline \multirow[t]{3}{*}{ Gender } & \multicolumn{8}{|c|}{ Sick-leave duration (days) } \\
\hline & \multicolumn{4}{|c|}{ Immigrants $(\mathrm{N}=1427)$} & \multicolumn{4}{|c|}{ Native-born $(\mathrm{N}=2793)$} \\
\hline & $\mathrm{N}$ & Mean & SD & Median & $\mathrm{N}$ & Mean & SD & Median \\
\hline Male & 113 & 17.4 & 28.1 & 8 & 273 & 29.7 & 36.8 & 13 \\
\hline Female & 68 & 22.8 & 31.2 & 10.5 & 277 & 37.3 & 41.1 & 20 \\
\hline
\end{tabular}

Table 4. Age-adjusted rate ratios (RR) for sick leave among the participants. (95\% Cl = 95\% confidence interval)

\begin{tabular}{|c|c|c|c|c|c|c|}
\hline & \multicolumn{6}{|c|}{ Model } \\
\hline & \multicolumn{2}{|c|}{ All patients } & \multicolumn{2}{|c|}{ Men } & \multicolumn{2}{|c|}{ Women } \\
\hline & $\mathrm{RR}$ & $95 \% \mathrm{Cl}$ & $\mathrm{RR}$ & $95 \% \mathrm{Cl}$ & $\mathrm{RR}$ & $95 \% \mathrm{Cl}$ \\
\hline Men versus women & 1.31 & $1.13-1.52$ & . & . & . & . \\
\hline $\begin{array}{l}\text { Natives versus } \\
\text { immigrants }\end{array}$ & 1.70 & $1.43-2.02$ & 1.43 & $1.14-1.79$ & 2.09 & $1.59-2.74$ \\
\hline
\end{tabular}

natives, and the median duration of all the age groups was also consistently higher.

The age-adjusted rate ratio for having at least one period of sick leave was greater for the native-born population (table 4). The adjusted overall rate ratio for the sick leaves of the natives, compared with those of the immigrants, was 1.7 (1.4 for the men and 2.1 for the women). The risk of sick leave among the native-born men was therefore around $40 \%$ greater than for the male immigrants, and, for the women, it was twice as high. When the data were analyzed without stratification by gender (table 4), we estimated a greater rate of sick leave (RR 1.3) for the men than for the women.

When adjusted for age, the estimated linear regression model for duration showed that the periods of sick leave averaged 1.5 times longer for the native workers than for the immigrant workers. The duration of sick leave was 1.3 times greater for the women than for the men.

The most frequent cause of sick leave among the immigrants was upper-back pain $(21.8 \%)$, followed by acute rhinopharyngitis $(9.3 \%)$ and gastroenteritis $(5.1 \%)$. Among the natives, the most frequent cause of sick leave was also upper-back pain (14.6\%), followed by anxiety disorders $(6.9 \%)$ and convalescence after surgical procedures $(5.7 \%)$.

\section{Discussion}

\section{Principal findings}

In this study, the immigrant patients took sick leave less frequently than their native-born counterparts. 
Furthermore, the mean duration of sick leave was shorter for the immigrants. However, there were no significant differences regarding the diseases causing sick leave among the native and immigrant groups.

Our research was carried out between March and $\mathrm{Au}-$ gust 2005. This timespan included the summer months when the inflow of immigrants was at its peak, but it also included a period of colder weather so that the differences in sick leave incidence due to seasonal influence could be examined. Some studies indicate that it is during the summer that the longest sick leaves occur $(15,16)$.

Our results are difficult to compare with those obtained in other studies due to differences in the analyses performed and the outcomes studied. However, a Spanish study carried out in Navarra by Parra et al (2) reported similar results, with $23 \%$ of the foreign-born workers and $30 \%$ of the native-born workers having some type of work disability during the study period (2). In our study, the duration of the sick leave was greater for the women than for the men. The results in the literature are inconclusive, since some studies report a shorter sick leave duration for women $(16,17)$, while others have reported a longer duration (18), and still others have reported no difference between the genders (19). A Spanish study (20) concluded that work absence does not depend on gender, but instead is related to personal characteristics and work conditions (flexibility of workhours, job status, type of contract, income, job prospects, etc). These features are particularly relevant in the case of the immigrant population. Several reports have found that the health of immigrant groups is perceived as a secondary issue. If workers are valued for their productivity, illness is obviously the worst possible scenario, both for the employer, who fears that production will slow down, and for the workers with precarious contracts, who may fear dismissal. Indeed, the situation of immigrant workers in a new environment may explain the principal differences found in the study (21).

The causes of sick leave among our patients were similar to those found in other studies $(22,23)$. Nevertheless, the use of different disease classification systems in these studies means that it is difficult to compare the results. As workers who seek medical consultation in primary care settings may have different characteristics than workers who do not go for consultation, the interpretation of the results of our study must be limited to similar populations.

It is well known that sick-leave duration depends on multiple factors, for instance, the specific health problem, workers' social and demographic characteristics, work conditions, and the activity performed. These factors may all contribute to explaining the differences found in our two groups. Benavides et al (24) stressed the importance of the type of work performed when the degree of sick leave is analyzed. Both in that study and the one by Artieda et al (25), workers in less-skilled jobs had longer mean disabilities per event and worker, in both the native and immigrant groups. Immigrant workers are more likely to be in good physical condition because of their lower mean age; in addition, people who decide to emigrate usually have acceptable health. Another explanation for the lower degree of sick leave among the immigrants may be their lack of job security and the adverse socioeconomic situations that motivate people to work while sick. This effect is called "presenteeism". It is well known that occupational category is an important predictor of sickness absence certified as attributable to common disease (26) and also that injuries and illnesses in vulnerable populations are probably underreported and health problems are more likely to be ignored (26-28). As immigrant workers tend to have poorer contracts, they are at a high risk of occupational injury and illness and are often discouraged from requesting better work conditions or reporting injury and illness due to their fear of reprisal (29).

\section{Limitations of our study}

Among the principal limitations of our study, the most important is the lack of work-related information in the clinical history register (numbers of persons in employment, type of work, type of contract, etc). Therefore, we could not analyze the extent to which differences in unemployment rates or job security might have explained the differences in the frequencies of sick leave between the two groups. Furthermore, our study was not based on an analysis of workers in the general population, but on patients consulting for primary care treatment. Finally, when sick-leave behavior is compared, only workers enrolled in the Spanish social security program were included; workers without full social security entitlement (that is, undocumented workers) were not included. The recent regularization program for undocumented immigrants may have increased the percentage of persons who work legally.

\section{Significance of the study and proposals for future research}

The reasons why immigrants require less sick leave than native workers and why their periods off-work tend to be of shorter duration should be analyzed in detail. Is it possible that immigrants, due to the precariousness of their situation, feel the need to work when ill? Or could immigrants be healthier than native workers? Immigration is a recent phenomenon in Spain, and most immigrants have arrived in the country recently. In the future, there will be greater differences among the immigrant population in terms of time spent in Spain. It will then be possible 
to examine whether time of residence is a factor that influences immigrants' attitudes towards work. Future research should explore whether the pattern identified in this study is reproduced in other areas of Spain and whether sick leave is attributable to different health needs or job characteristics.

\section{Concluding remarks}

In summary, these results suggest that sick leave was less frequent among immigrants than among natives in this study in Lleida (Spain) and that immigrant disabilities were of shorter duration. Nevertheless, no differences were detected between the causes of disability in the two study populations. This study adds to the body of empirical information on immigrant sick leave, and this information is of vital importance in the framing of public perception, debate, and policy.

\section{Acknowledgments}

We would like to thank our colleagues at the primary care centers for participating in the study and enrolling the study participants.

This study was carried out with support from the Sociedad Española de Medicina Familiar y Comunitaria (SemFYC).

\section{References}

1. Soler J. Nuevos residentes en la ciudad de Lleida [New residents in Lleida] [cited 14 May 2008]. Buttl Mèdic. 2005;53:67. Available from: http://www.comll.cat/comll/imageDisplay. do?fitxerId=32.

2. Parra A, Fernández J, García V, Ayestarán JR, Extramiana E. Mercado de trabajo, salud laboral e inmigración [Labor market, occupational health and immigration]. An Sist Sanit Navar. 2006;29:77-95.

3. Nygård C-H, Huuhtanen P, Tuomi K, Martikainen R. Perceived work changes between 1981 and 1992 among aging workers in Finland. Scand J Work Environ Health. 1997;23 suppl $1: 12-9$.

4. Barreto SM, Swerdlow AJ, Schoemaker MJ, Smith PG. Predictors of first nonfatal occupational injury following employment in a Brazilian steelworks. Scand J Work Environ Health. 2000;26(6):523-8.

5. Secretaría de Estado de inmigración y emigración. Ministerio de Trabajo y Asuntos Sociales: anuario estadístico 2005 [Ministry of Employment and Social Affairs: annual statistics for 2005]. Madrid (Spain): Ministerio de Trabajo y Asuntos Sociales; 2005 [cited 14 May 2008]. Available from: http://www. ine.es/prodyser/pubweb/anuarios_mnu.htm.

6. Ahonen EQ, Benavides FG, Benach J. Immigrant populations, work and health—a systematic literature review. Scand J Work
Environ Health. 2007;33(2):96-104.

7. Rue M, Serna MC, Soler-Gonzalez J, Bosch A, Ruiz-Magaz MC, Galvan L. Differences in pharmaceutical consumption and expenses between immigrant and Spanish-born populations in Lleida, (Spain): a 6-months prospective observational study. BMC Health Serv Res. 2008;8:35.

8. Rue M, Cabré X, Soler-Gonzalez J, Bosch A, Almirall M, Serna MC. Emergency hospital services utilization in Lleida (Spain): a cross-sectional study of immigrant and Spanish-born populations. BMC Health Serv Res. 2008;8:81.

9. Akhavan S, Bildt C, Wamala S. Work-related health factors for female immigrants in Sweden. Work. 2007;28(2):135-43.

10. Löfvander M, Engström A. An observer-participant study in primary care of assessments of inability to work in immigrant patients with ongoing sick leave. Scand J Prim Health Care. 2003;21(4):199-204.

11. Akhavan S, Bildt CO, Franzén EC, Wamala S. Health in relation to unemployment and sick leave among immigrants in Sweden from a gender perspective. J Immigr Health. 2004;6(3):103-18.

12. Löfvander M. Attitudes towards pain and return to work in young immigrants on long-term sick leave. Scand J Prim Health Care. 1999;17(3):164-9.

13. Cots F, Castells X, Garcia O, Riu M, Felipe A, Vall O. Impact of immigration on the cost of emergency visits in Barcelona (Spain). BMC Health Ser Res. 2007;7;9-18.

14. Garcia Campayo J, González C, Buil B, Garcia Luengo M, Caballero L, Collazo F. Actitudes de los médicos españoles hacia los pacientes inmigrantes: una encuesta de opinión [Attitudes of Spanish doctors towards immigrant patients: an opinion survey]. Actas Esp Psiquiatr. 2006;34;371-6.

15. Mesa FR, Kaempffer AM. 30 años de estudio sobre ausentismo laboral en Chile: una perspectiva por tipos de empresas [Work absenteeism in Chile according to the type of work place]. Rev Méd Chile. 2004;132:1100-8.

16. González-Barcala FJ, Cadalso-Suárez C, Valdés-Cuadrado L, Lado-Lema ME, Bugarín-González R, et al. Determinantes de la duración de la incapacidad temporal y la vuelta al trabajo en un área sanitaria de Galicia [Factors determining the duration of temporary disability and return to work in a health district of Galicia]. Aten Primaria. 2006;37:431-8.

17. Yuh Jang, Wenshu Li, Mann-Tsong Hwang. Factors related to returning to work following a work-oriented occupational therapy program for individuals with physical disabilities. J Occup Rehabil. 1998;8:141-51.

18. Benavides FG, Sáez M, Barceló, Serra C, Mira M. Incapacidad laboral: estrategias de análisis [Temporary disability: analysis strategies]. Gac Sanit. 1999;13:185-90.

19. Krause N, Dasinger LK, Deegan LJ, Sullivan TJ, Sinclair SJ. Psychosocial job factors and return-to-work after compensated low back injury: a disability phase-specific analysis. Am J Ind Med. 2001;40:374-92.

20. Ministerio de Trabajo y Asuntos Sociales. El absentismo laboral de las mujeres: en relación con el de los hombres [Absenteeism among women and men: a comparison]. Madrid: Consultrans SA; 2000 [Cited 14 May 2008]. Available from: http://www.migualdad.es/mujer/mujeres/estud_inves/2000/ 502p.pdf.

21. Berra S, Elorza Ricart JM, Bartomeu N, Hausmann S, SerraSutton V, Rajmil L. Necessitats en salut i utilització dels serveis sanitaris en la població immigrant a Catalunya: revisió exhaustiva de la literatura científica [Health needs and the use of health services among the immigrant population in Catalonia: an exhaustive review of the literature]. Barcelona (Spain): 
Agència d'Avaluació de Tecnologia i Recerca Mèdiques; 2004. [cited 14 May 2008]. Available from: http://www.gencat. net/salut/depsan/units/aatrm/pdf/in0401ca.pdf.

22. Ugalde Díez M, Alberquilla Menéndez-Asenjo Á, González Rodríguez-Salinas C, Pilas Pérez M, Rivera Guzmán JM. Perfiles de duración de incapacidad laboral transitoria en un distrito sanitario y su comparación con algunos estándares propuestos [Profiles of the duration of temporary work incapacity in a health district and its comparison with some proposed standards]. Gac Sanit. 1996;10:293-8.

23. Leroux I, Dionne CE, Bourbonnais R. Psychosocial job factors and the one-year evolution of back-related functional limitations. Scand J Work Environ Health. 2004;30(1):47-55.

24. Benavides FG, Plana M, Serra C, Dominguez R, Despuig $\mathrm{M}$, Aguirre S, et al. Incapacidad temporal por contingencia común: papel de la edad, el sexo, la actividad económica y la Comunidad Autónoma: Navarra 2003 [Return to work after a non-work related sick spell: the role of age, sex, economic activity and autonomous community: Navarra 2003]. Rev Esp Salud Publica. 2007;81:183-90.

25. Artieda A, Ceberio P, Cipriain C, Extramiana E, Fernández J, Iriarte L, et al. Incapacidad temporal por enfermedad común y accidente no laboral [Temporary work incapacity due to com- mon illness and non-work-related accident: Navarre 2003]. Navarre (Spain): Gobierno de Navarra, Departamento de Salud, Instituto Navarro de Salud Laboral; 2005 [cited 14 May 2008]. Available from: http://www.cfnavarra.es/insl/doc/ITNavarra2003.pdf.

26. Benavides FG, Benach J, Mira M, Sáez M, Barceló A. Occupational categories and sickness absence certified as attributable to common diseases. Eur J Public Health. 2003;13:51-5.

27. Hansen AR, Krasnik A, Høg E. Access to health care for undocumented immigrants: rights and practice. Dan Med Bull. 2007;54:50-1.

28. Den Otter JJ, Tavenier D. Right to health care for vulnerable migrants. Lancet. 2007;370(9590):828.

29. Soler-González J, Serna C, Rué M, Bosch A, Ruiz MC, Gervilla J. Utilización de recursos de asistencia primaria por parte de inmigrantes y autóctonos que han contactado con los servicios asistenciales de la ciudad de Lleida [Use of primary care resources by immigrants and the autochthonous persons who contact the care services in the city of Lleida, Spain]. Aten Primaria. 2008;40(5):225-33.

Received for publication: 29 February 2008 